\title{
MEASUREMENT AND ANALYSIS OF THE NOISE LEVEL IN SELECTED ZONES OF BUS STOPS IN THE CITY OF RADOM
}

\section{Tomasz Perzyński}

Faculty of Transport, Electrical Engineering and Computer Science, Kazimierz Pulaski University of Technology and Humanities in Radom, Poland

*E-mail of corresponding author: t.perzynski@uthrad.pl

\section{Resume}

The noise from means of transport is one of the main factors of environmental noise pollution and is one of the factors having an effect on human health. The article presents the problem of noise emitted by urban means of transport. The work focuses on analysis of the acoustic climate in the bus stop zone. In order to estimate the noise level, research was conducted in selected points in one of the Polish cities - Radom. The obtained results allowed assessment of the impact of transport on the noise level in the area of selected bus stops.

\section{Introduction}

Noise is a complex issue, emitted by various sources, which is a serious problem for the human environment [1]. It is defined as unwanted sound [2]. It negatively affects human health and is an important public health problem [3]. Noise is the second most harmful factor after the polluted air, which affects the environment. One of the sources of noise that people fight with every day is the noise generated by means of transport. According to European Commission data, the road transport has the greatest impact on noise levels [4]. Other places include: rail transport, air transport and industry [5]. In the European Union, more than 210 million people are affected by the street noise [6]. As estimated over 10 years ago, social costs of noise reached $2 \%$ of GDP [7]. Regarding the Directive [8], the noise protection is an element that achieves a high level of health and environmental protection. This directive obliges Member States and their local government units to create the noise maps and to make acoustic planning. In addition to the abovementioned directive, individual EU member states have their own appropriate legal acts defining its acceptable level [9]. Scientists and engineers are trying to identify technologies and methods that can help reduce noise. However, the problem is the lack of uniform regulations for all the member states. Noise from the means of the city transport is such an important social problem that many researchers deal with its analysis. The problem of the street noise affects adults, children and animals. Even moderate road traffic disturbs cognitive function, especially in children [10]. The authors of [11] presented correlation between the blood pressure in children and the noise from public transport. They showed that the street noise was associated with an increase in systolic pressure. On the other hand, the authors in [12] showed a relationship between noise from means of transport and blood pressure of adults.

A helpful tool in reducing the noise is modeling and forecasting, which was presented in [13-14]. The authors of [15] conducted an analysis of effects of the road traffic on people's state of mind. The authors [16] proposed a multicriteria tool to support decision making regarding the road noise activities. As indicated in the study [17], the problem of road noise also applies to the nighttime. In addition, in [18], the authors investigated the impact of the urban noise on sleep. Test results indicated that noise has an impact on quality of sleep and level of rest. The authors of [19] indicate, however, that increased noise at night increases the risk of cardiovascular diseases. In the paper [20], the authors present the results of research on representative sample of the US urban adolescents. The results showed a correlation between noise and bedtime.

As the number of motor vehicles increases, so does the number of people exposed to noise hazards. It should be noted that in most cases noise measurements only 


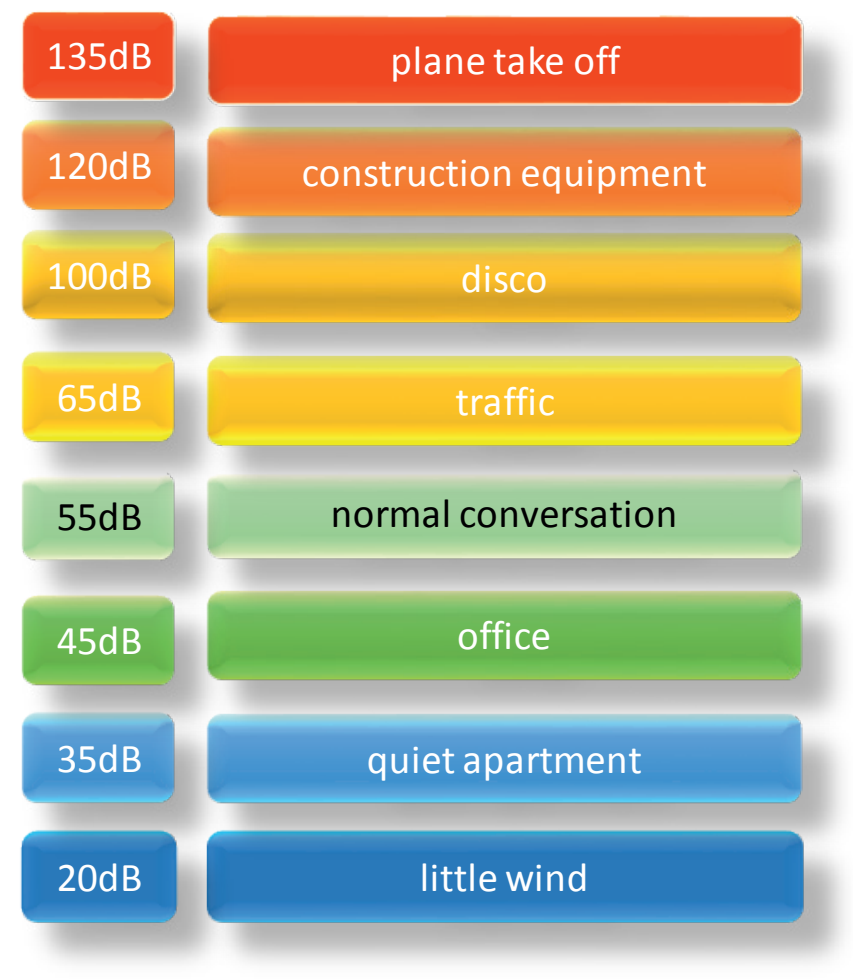

Figure 1 Approximate sound level values

Table 1 Rolling noise requirements [25]

\begin{tabular}{ccc}
\hline tyre class & nominal section width $(\mathrm{mm})$ & limit values in $\mathrm{dB}(\mathrm{A})$ \\
\hline $\mathrm{C} 1 \mathrm{~A}$ & $\leq 185$ & 70 \\
$\mathrm{C} 1 \mathrm{~B}$ & $>185 \leq 215$ & 71 \\
$\mathrm{C} 1 \mathrm{C}$ & $>215 \leq 245$ & 71 \\
$\mathrm{C} 1 \mathrm{D}$ & $>245 \leq 275$ & 72 \\
$\mathrm{C} 1 \mathrm{E}$ & $>275$ & 74 \\
\hline
\end{tabular}

apply to the human audible band. This band is in the range of $20 \mathrm{~Hz}-20 \mathrm{kHz}$. Noise testing is also an important issue for frequencies below $20 \mathrm{~Hz}$ (infrasound) and above 20 $\mathrm{kHz}$ (ultrasound). Infrasound waves can be a source of anxiety, fear and even depression. Ultrasounds are used in medicine or technological processes, but in this case they are controlled processes. Other uncontrolled sources of ultrasound emissions may be harmful to human health, as indicated in [21].

The article presents the measurements results of noise emitted by means of transport in the area of selected public transport stops, city of Radom (Poland). The city of Radom is a medium-sized city (about 200.000 inhabitants) located in the central-eastern part of Poland. The measurements were carried out while passengers were waiting for the bus to arrive. The authors of [22] presented similar concept of research related to noise, among others at bus stops, however, the research was focused on analysis of noise during the bus approaching the bus stop and departure from the stop.

The measurements were carried out at four selected points of the city. The data obtained allowed estimation of an equivalent sound level for each bus stop zone. Due to exceeding the maximum values of the noise level in one zone (access road to the center - city beltway), detailed measurements of the traffic intensity were carried out.

\section{Transport noise and its sources}

Noise is an unwanted sound. The measure of sound intensity is the sound pressure level. This level is measured in decibels $(\mathrm{dB})$, which is usually given in relation to the level of the corrected sound measurement value according to audio filter $\mathrm{A}-\mathrm{dB}(\mathrm{A})$. Filter A allows to optimize the measurement due to the characteristics of human hearing. It is worth to note that decibel is a logarithmic unit. One $\mathrm{dB}$ more causes a $26 \%$ increase in energy compared to the previous state ( $2 \mathrm{~dB}$ is a $59 \%$ increase). Figure 1 shows approximate values of sound intensity in different surroundings.

Factors affecting the level of noise from the road transport can include:

- the number of vehicles traveling in a unit of time, 
permissible noise levels in $(\mathrm{dB})$

roads or railways

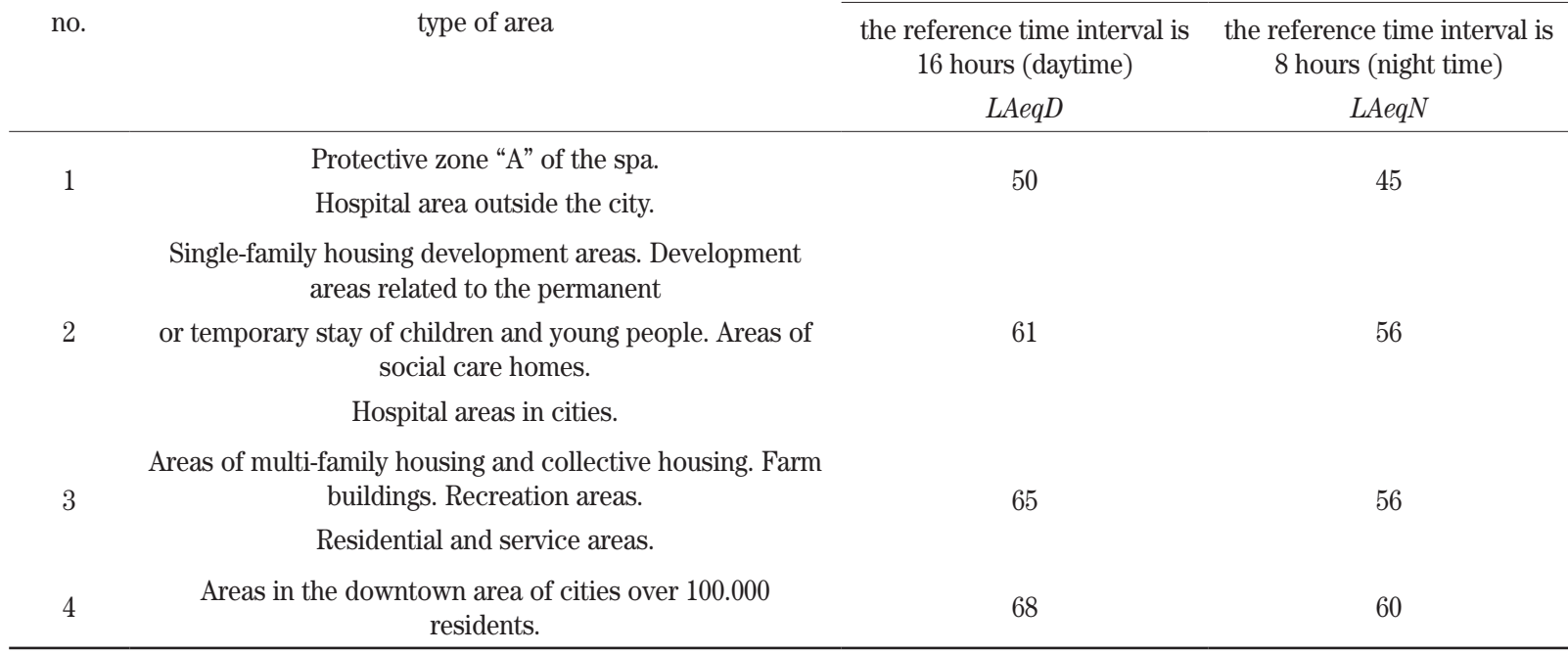

- type of tyres,

- driving type,

- speed of motor vehicles,

- technical condition of motor vehicles,

- pavement type,

- technical condition of the pavement,

- meteorological conditions,

- aerodynamics of a motor vehicle.

Regarding the factors mentioned above, one of the main factors is noise from vehicle tyres. It becomes the dominant source of noise at speeds above $35 \mathrm{~km} / \mathrm{h}$ (for passenger vehicles) and above $60 \mathrm{~km} / \mathrm{h}$ for heavy vehicles [23]. As indicated by authors of study [24], the noise of the tyre interaction with the road pavement becomes dominant for the speed of passenger vehicles above $40 \mathrm{~km} / \mathrm{h}$ and for heavy goods vehicles above $70 \mathrm{~km} / \mathrm{h}$. Table 1 presents data on noise limit values for the summer tyres according to passenger cars (class $\mathrm{C} 1$ ). For the snow tyres the limits shall be increased by $1 \mathrm{~dB}(\mathrm{~A})$ [25].

Currently, tyres are available for passenger cars with the noise levels starting from $66 \mathrm{~dB}$, although the typical values are around 70-71dB. As authors of [26] indicate, connecting a quiet tyre with an appropriate pavement can reduce noise by $6 \mathrm{~dB}$. The noise from the road pavement and that related to the speed of vehicles is also significant. Reducing the speed from $70 \mathrm{~km} / \mathrm{h}$ to $50 \mathrm{~km} / \mathrm{h}$ can reduce noise by more than $5 \mathrm{~dB}$. The study of the pavement type impact on the noise generated by the tyre is presented in publications [24] and [27]. Authors of [28] have presented the methodology for assessing noise at the interface between the road pavement and the tyre. They also showed a relationship between the type of pavement, its age and impact on noise levels. Authors of [29] and [30] presented the dependence of noise from the motor vehicles on dry and wet surfaces. The problem of noise coming from the motor vehicles concern not only vehicles in motion but also standing e.g. in traffic jams. Authors of [31] drew attention to the problem of noise generated by standing vehicles at various levels of engine speed. In the case of the urban zone, buildings and landforms are also a problem with reference to noise. The noise in this case is affected by reflection and diffraction of the waves. Therefore, appropriate urban planning measures can contribute to reducing the noise levels.

\section{$3 \quad$ Parameters and indicators}

Measurements of environmental noise coupled with traffic can be made using [1]:

- $\quad$ indirect method (single acoustic events),

- direct method of measuring noise using sampling,

- $\quad$ direct continuous measurement method for a limited time.

One of the criteria for choosing the method of measuring noise is the volume of vehicle traffic. For roads over 300 vehicles / hour it is recommended to use the direct method with the use of sampling [32].

In accordance with announcement of the Polish Minister of the Environment of October 15, 2013 regarding the publication of a uniform text of the Regulation of the Minister of the Environment on permissible noise levels in the environment, Table 2 presents the permissible noise levels in the environment, excluding:

- take-offs, landings and flights of aircraft,

- power lines.

Acceptable noise levels were expressed by the indicators $L A e q D$ and $L A e q N$, which mean:

- $L A e q D$ - indicator for the equivalent sound level for the daytime (from 6.00 to 22.00), expressed in [dB],

- $\quad L A e q N$ - indicator for the equivalent sound level for the night (from 10:00 p.m. to 6:00 a.m.), expressed in [dB].

- $\quad L A e q(\mathrm{D}$ and N) can be calculated based on the formula:

$L A_{e q}=10 \log \left(\frac{1}{T} \sum_{i=1}^{n} \tau_{i} 10^{0.1 L_{i}}\right)$,

where: 
a)

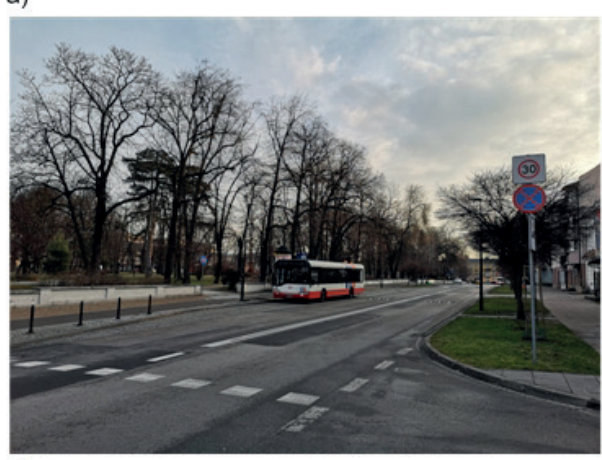

c)

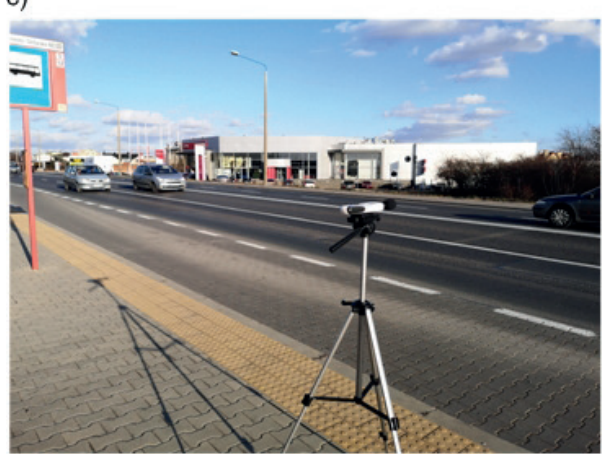

b)

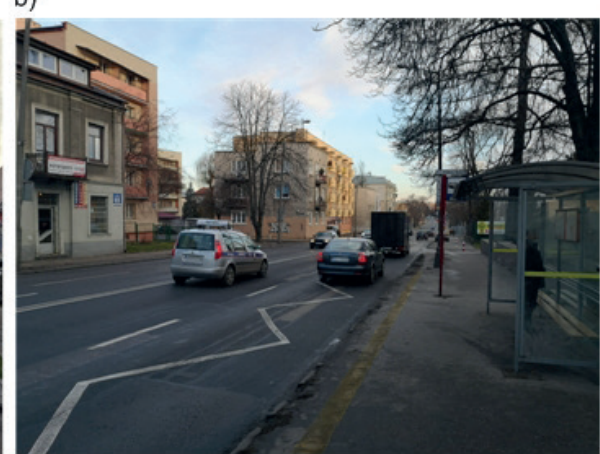

d)

Figure 2 Location of the measuring zones: a) center zone "30", b) downtown c) access road to the center - city beltway, d) downtown - shopping mall

$L_{i}$ - sound level over a period of time,

$\tau_{i}$ - duration of noise level $L_{i}$,

$T$ - observation time.

Based on the data obtained, the mean logarithmic exposure value for each series can be estimated according to:

$$
L_{A d \min }=10 \log \left(\frac{1}{n} \sum_{i=1}^{n} 10^{0.1 L A e}\right)
$$

where:

$L_{A e}$ is the exposure level for a single acoustic event and $n$ is the number of events in the series.

Standard deviation can be estimated based on expression:

$$
\sigma=\sqrt{\frac{1}{n-1} \sum_{i=1}^{n}\left(L_{A e}-L_{A d \min }\right)^{2}}
$$

\section{Research and measurement results}

To measure the sound level of transport means in the city of Radom, the sound meter Steinberg SBS-SM-130C was used. Measuring device data: meter operating band $31.5 \mathrm{~Hz}-8 \mathrm{kHz}$, accuracy $+/-1.4 \mathrm{~dB}$. The measuring device has been set up to perform measurements according to A - weighted sound level for the FAST time constant. With reference to recommendations contained in [32], a direct measurement method using sampling was proposed for measurements. The measuring device was set on a tripod, height from the ground $1.5 \mathrm{~m}$ in the stop zone. Despite the good conditions (weak wind), the microphone had a windscreen. In all the measuring sessions measurements were made in meteorological conditions ensuring stable conditions: temperature above $2{ }^{\circ} \mathrm{C}$, light wind, moderate cloud cover, no rainfall. Measurements were carried out on sections where the road pavement was made of asphalt, good condition, no defects in the road.

Four places were selected for the measurements:

- $\quad$ city center - zone 30 ,

- downtown,

- access road to the city center, beltway,

- $\quad$ city center - shopping mall.

The measurement sites were located in the bus stops area. The measurement hours were set for morning and afternoon hours on different days of the week (excluding weekends). All the measurements points were in the urban zone - the city of Radom, Poland. Two measuring sessions were carried out in each zone on different days. It was assumed that the average waiting time of passengers at the bus stop is about 5 minutes. Every $5 \mathrm{~s}$ instantaneous sound pressure values were read. Figure 2 shows locations of zones where the measurements were carried out.

Based on Equations (1), to (3), calculations were carried out, results of which are shown in Table 3.

Taking into account the higher of the average values for each zone $\left(L_{\text {mid }}\right.$ - Table 3$)$, Figure 3 shows the graphical form of the collected data for measurement session $2,4,6$ and 7.

Since in the zone of the access street to the center the city beltway, the permissible noise level values were exceeded, it was decided to carry out an additional test to obtain data on the number of vehicles, vehicle speed, type of vehicles. The tests were carried out for one direction of 

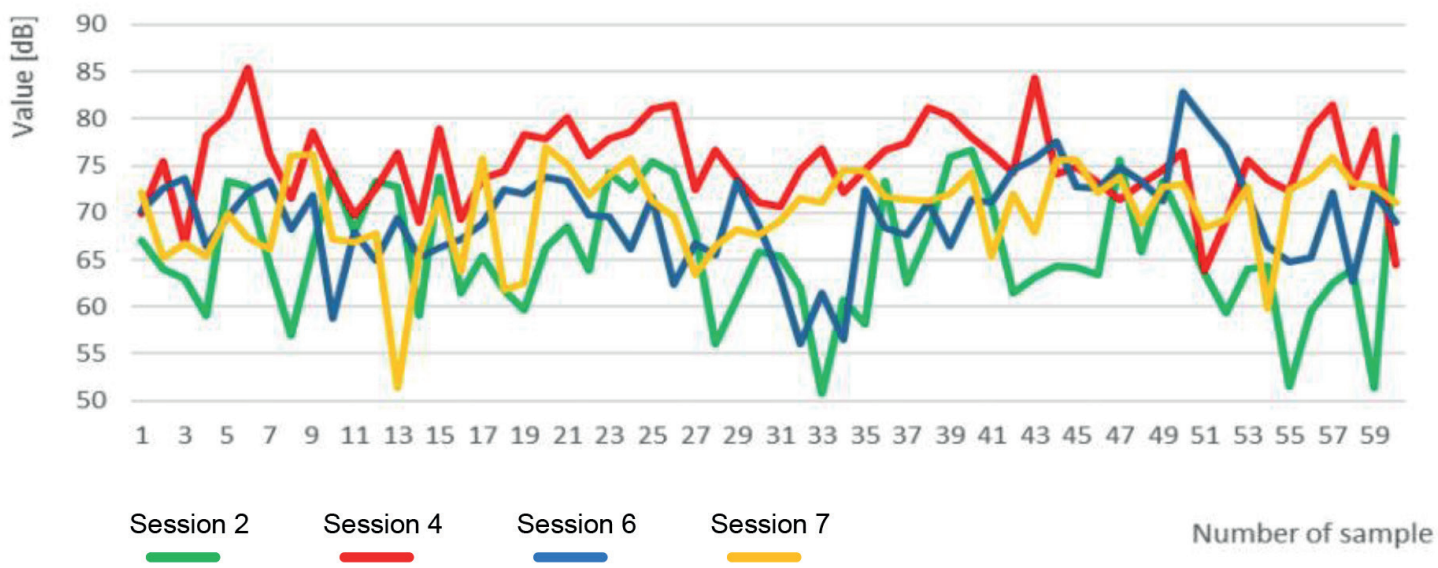

Figure 3 Graphical form of the collected data-measurement session 2, 4, 6 and 7

Table 3 Calculation results for collected measurement data

\begin{tabular}{ccccc}
\hline zone & session number & $L_{\text {mid }}(\mathrm{dB})$ & $L_{e q D}(\mathrm{~dB})$ & $\sigma(\mathrm{dB})$ \\
\hline \multirow{2}{*}{ city center "30" } & 1 & 68.25 & 61.26 & 8.04 \\
beltway & 2 & 69.91 & 62.91 & 6.55 \\
& 3 & 77.03 & 70.03 & 6.06 \\
downtown (25 Czerwca st.) & 4 & 77.25 & 70.26 & 4.4 \\
& 5 & 71.58 & 64.85 & 4.58 \\
downtown - shopping mall & 6 & 72.35 & 65.35 & 5.09 \\
& 7 & 61.99 & 62.99 & 4.73 \\
\hline
\end{tabular}

Table 4 Results of the vehicle traffic measurements - the city beltway - Kielecka Street

\begin{tabular}{ccccc}
\hline speed range & car & vans & heavy & together \\
\hline $21-30 \mathrm{~km} / \mathrm{h}$ & 0 & 0 & 1 & 1 \\
$31-40 \mathrm{~km} / \mathrm{h}$ & 0 & 0 & 0 & 0 \\
$41-50 \mathrm{~km} / \mathrm{h}$ & 16 & 1 & 9 & 26 \\
$51-60 \mathrm{~km} / \mathrm{h}$ & 46 & 4 & 13 & 63 \\
$61-70 \mathrm{~km} / \mathrm{h}$ & 34 & 5 & 4 & 43 \\
$71-80 \mathrm{~km} / \mathrm{h}$ & 9 & 0 & 1 & 10 \\
$81-90 \mathrm{~km} / \mathrm{h}$ & 1 & 0 & 1 & 2 \\
$>90 \mathrm{~km} / \mathrm{h}$ & 0 & 0 & 0 & 0 \\
\hline together & 106 & 10 & 29 & 145 \\
\hline
\end{tabular}

travel. The ViaCount II traffic meter, which works based on the Doppler radar, was used to conduct the tests. Speed limit on the test section of the road: $50 \mathrm{~km} / \mathrm{h}$. Measurements were made: 03-02-2020 from 16:43:39 to 16:54:50. Results are shown in Table 4.

On the examined section 145 vehicles were registered, including 106 passenger vehicles, 10 delivery vehicles, 29 heavy vehicles.

\section{Discussion of the results}

The main purpose of the measurements was to determine the current state of the acoustic climate in areas subjected to acoustic protection, which are in the zone of selected bus stops. The research has been in a pilot-phase to indicate potential bus stop zones that should be analyzed in terms of improving the acoustic climate. To carry out the measurements it was decided to use the direct measurement method in the form of sampling. Measurements have shown that the noise from means of transport is not in all the bus stop zones below the permissible values specified in the Regulation [33]. Calculations made for "zone 30" showed that the noise was there at the lowest level and was below the permissible values. In the downtown area noise levels were also below the permissible values, however, higher than for "zone 30". The highest levels were recorded at the bus stop on the city beltway, Kielecka Street. The 
estimated equivalent sound level of $\operatorname{LeqD}$ was: $70.03 \mathrm{~dB}$ and $70.26 \mathrm{~dB}$. In the other examined zones, the noise from means of transport was not exceeded, however, due to the relatively high results, further tests should be carried out. It is worth adding that the World Health Organization (WHO) in its report [34] recommends limiting the LeqD value below $53 \mathrm{~dB}$ (recommendation for the road traffic), considering it as a value above which it causes adverse effects on human health. It should also be noted that in Poland the limit values indicated in [33] for the city center zone were raised about $3 \mathrm{~dB}$ in relation to the Act [35] of 2007 (before amendment). With some anxiety one can also note the fact that in the case of pollution caused by motor vehicles (exhaust), we are dealing with the introduction of new restrictions, in the case of transport noise such restrictions cannot be seen.

It should be noted that the highest traffic intensity was noted on Kielecka Street - the city beltway. Therefore, for this bus stop zone additional research was carried out to measure vehicle traffic. For this purpose, measurements were taken on February 3, 2020, measurement time $\sim 12$ minutes. The research was made in the afternoon due to the dusk and to skipping the drivers' reaction to see the radar. There is a speed limit of $50 \mathrm{~km} / \mathrm{h}$ on the analyzed road section. During the analysis 145 vehicles were registered (in one direction). The analysis shows that as much as $81.38 \%$ of the vehicles were traveling at speeds above the maximum permissible (118 vehicles). As many as 55 vehicles traveled at speeds above $61 \mathrm{~km} / \mathrm{h}$. For heavy goods vehicles: 19 vehicles were traveling at speeds over $51 \mathrm{~km} / \mathrm{h}$. One of the causes of increased noise values on the examined road section can be excessive speed of the vehicles.

The obtained results allow the commencement of research related to use of the noise reduction solutions at selected stops. The next stage may be the analysis of the construction of the bus shelters, their reconstruction toward use as acoustic screens.

\section{Conclusion}

Undoubtedly, the urban transport noise, its reduction, must be a part of further research and analysis. The need to develop acoustic maps of cities, indicated by the European Commission, will allow, at the stage of urban spatial planning, to introduce solutions that can reduce the traffic noise. Building parks is a natural method of reducing urban noise. The so-called green screens can effectively protect against the street noise. Use of active transport telematics systems can also be an effective solution. Such a system could continuously analyze the noise level in a given urban area and, if necessary, limit the speed of vehicles, which in combination with the appropriate road pavement can bring measurable effects in the form of a lower noise level. As indicated in the paper, first of all, drivers must comply with speed limits. Reducing the speed of a truck from $60 \mathrm{~km} / \mathrm{h}$ to $50 \mathrm{~km} / \mathrm{h}$ reduces the noise for almost $2 \mathrm{~dB}$ [36]. Effective measures to prevent excessive levels of the traffic noise is to reduce the number of vehicles and to use the better technologies (tyres, surfaces) [37]. Reducing the number of vehicles in cities is possible by promoting the public transport [38]. As the tests of one of the electric bus manufacturers show, use of the electric propulsion in buses, instead of an internal combustion engine, in the urban speed range (up to $50 \mathrm{~km} / \mathrm{h}$ ) can be seen to reduce the external noise by up to $8 \mathrm{~dB}$ [39]. Noise or pollution reduction can also be limited by the proper urban traffic management, e.g. by optimizing traffic light control systems [40]. There is no doubt that only coherent actions towards the use of new technologies, full vehicle traffic control, regulations and urban planning can reduce the noise which surrounds us every day.

\section{References}

[1] GORZELANCZYK, P. The road transport noise emission in Pila (in Polish). Autobusy. 2016, 6, p. 876-880. ISSN 1509-5878.

[2] Commonwealth of Australia as represented by the Department of Health. The health effects of environmental noise. Publications Number: 12214. 2018.

[3] Word Health Organization. Environmental noise. Guidelines for the European Region. 2018.

[4] Road traffic remains biggest source of noise pollution in Europe - European Environment Agency [online] [accessed 2020-01-30]. Available from: https://www.eea.europa.eu/highlights/road-traffic-remains-biggest-source

[5] European Commission. Science for environment policy. Noise abatement approaches. Issue 17.2017. ISBN 978-92-79-67011-4.

[6] JACYNA, M., WASIAK, M., LEWCZUK, K., KARON, G. Noise and environmental pollution from transport: Decisive problems in developing ecologically efficient transport systems. Journal of Vibroengineering [online]. 2017, 19, p. 5639-5655. ISSN 1392-8716, eISSN 2538-8460. Available from: https://doi.org/10.21595/jve.2017.19371

[7] FIGLUS, T., GNAP, J., SKRUCANY, T., SZAFRANIEC, P. Analysis of the influence of different means of transport on the level of traffic noise. Scientific Journal of Silesian University of Technology. Series Transport [online]. 2017, 97, p. 27-38. ISSN 0209-3324, eISSN 2450-1549. Available from: https://doi.org/10.20858/sjsutst.2017.97.3

[8] Directive 2002/49/EE of The European Parliament and of The Council of 25 June 2002 relating to the assessment and management of environmental noise.

[9] Handbook on the implementation of EC environmental legislation. Section 9 - Noise legislation [online]. 2020. Available from: https://ec.europa.eu/environment/archives/enlarg/handbook/noise.pdf (12-01-2020) 
[10] BHATIA, R. Noise pollution: managing the challenge of urban sounds [online] [accessed 2020-02-13]. Available from: https://earthjournalism.net/resources/noise-pollution-managing-the-challenge-of-urban-sounds

[11] PAUNOVIC, K, BELOJEVIC, G, JAKOVLJEVIC, B. Blood pressure of urban school children in relation to road-traffic noise, traffic density and presence of public transport. Noise and Health [online]. 2013, 15, p. 253-260. ISSN 1463-1741, eISSN 1998-4030. Available from: http://www.noiseandhealth.org/text.asp?2013/15/65/253/113521

[12] DRATVA, J., PHULERIA, H., FORASTER, M., GASPOZ, J.-M., KEIDEL, D., KUNZLI, N., LIU, L.-J., PONS, M., ZEMP, E., SCHINDLER, CH. Transportation noise and blood pressure in a population-based sample of adults. Environmental Health Perspectives [online]. 2011, 120(1), p. 50-55. ISSN 1552-9924. Available from: https://doi.org/10.1289/ehp.1103448

[13] MELO, R. A., PIMENTEL, R. L., LACERDA, D. M., SILVA, W. M. Applicability of models to estimate traffic noise for urban roads. Journal of Environmental Health Science and Engineering [online]. 2015, 13, 83. eISSN 2052-336X. Available from: https://doi.org/10.1186/s40201-015-0240-9

[14] ECE, M., TOSUN, I., EKINCI, K., YALCINDAG, N. S. Modeling of road traffic noise and traffic flow measures to reduce noise exposure in Antalya metropolitan municipality. Journal of Environmental Health Science and Engineering [online]. 2018, 16, 1. eISSN 2052-336X. Available from: https://doi.org/10.1007/s40201-018-0288-4

[15] GOKDAG, M. Study of the road traffic noise in Erzurum-Turkey. Iranian Journal of Environmental Health Science and Engineering [online]. 2012, 9, 22. eISSN 2052-336X. Available from: https://doi.org/10.1186/1735-2746-9-22

[16] RUIZ-PADILlO, A., RUIZ, D., TORIJA, A., RAMOS-RIDAO, A. Selection of suitable alternatives to reduce the environmental impact of road traffic noise using a fuzzy multi-criteria decision model. Environmental Impact Assessment Review [online]. 2016, 61, p. 8-18. ISSN 0195-9255. Available from: https://doi.org/10.1016/j.eiar.2016.06.003

[17] MURPHY, E., KING, E., RICE, H. Estimating human exposure to transport noise in central Dublin, Ireland. Environment International [online]. 2008, 35(2), p. 298-302. ISSN 0160-4120. Available from: https://doi.org/10.1016/j. envint.2008.07.026

[18] STOSIC, L., BELOJEVIC, G., MILUTINOVIC, S. (2009). Effects of Traffic Noise on sleep in an urban population. Arhiv za Higijenu Rada $i$ Toksikologiju [online]. 2009, 60, p. 335-342. ISSN 0004-1254, eISSN 1848-6312. Available from: https://doi.org/10.2478/10004-1254-60-2009-1962

[19] BABISCH, W. Transportation noise and cardiovascular risk. Review and synthesis of epidemiological studies. Dose-effect curve and risk estimation [online]. 2006. ISSN 0175-4211. Available from: http://www.umweltbundesamt.de

[20] RUDOLPH, K., SHEV, A., PAKSARIAN, D., MERIKANGAS, K., MENNITT, D., JAMES, P., CASEY, J. Environmental noise and sleep and mental health outcomes in a nationally representative sample of urban US adolescents. Environmental Epidemiology [online]. 2019, 13(3(4)), e056. eISSN 2474-7882. Available from: https://doi.org/10.1097/ EE9.0000000000000056

[21] SMAGOWSKA, B. \& PAWLACZYK-LUSZCZYNSKA, M. (2013). Effects of Ultrasonic Noise on the Human Body-A Bibliographic Review. International Journal of Occupational Safety and Ergonomics: JOSE. 19. 195-202. 10.1080/10803548.2013.11076978.

[22] GERSHON, R., NEITZEL, R., BARRERA, M., AKRAM, M. Pilot survey of subway and bus stop noise levels. Journal of Urban Health [online]. 2006, 83, 802. ISSN 1099-3460, eISSN 1468-2869. Available from: https://doi.org/10.1007/s11524006-9080-3

[23] CEDR report 2017/03. State of the art in managing road traffic noise: summary report. [online]. 2020. Available from: https://www.cedr.eu/download/Publications/2017/CEDR2017-03-State-of-the-art-in-managing-road-traffic-noise.pdf

[24] LINK, R. E., BENNERT, T., HANSON, D., MAHER, A. VITILLO, N. Influence of pavement surface type on tire/pavement generated noise. Journal of Testing and Evaluation [online]. 2005, 33(2), p. 94-100. ISSN 0090-3973. Available from: https://doi.org/10.1520/JTE12641

[25] Regulation (EC) No 1222/2009 of the European Parliament and of the Council of 25 November 2009 on the labelling of tyres with respect to fuel efficiency and other essential parameters

[26] BERGE, T., MIODUSZEWSKI, P., EJSMONT, J., SWIECZKO-ZUREK, B. Reduction of road traffic noise by source measures - present and future strategies. Noise Control Engineering Journal [online. 2017, 65(6), p. 549-559. ISSN 0736-2501. Available from: https://doi.org/10.3397/1/376568

[27] LI, T. (2018). Literature review of tire-pavement interaction noise and reduction approaches. Journal of Vibroengineering [online]. 2018, 20, p. 2424-2452. ISSN 1392-8716, eISSN 2538-8460. Available from: https://doi.org/10.21595/jve.2018.19935

[28] BOODIHAL, M., CHETHAN, A., RUDRARADHYA, S., SAHU, R., BILIGIRI, K. P. Development of tyre/road noise assessment methodology in India. Case Studies in Construction Materials [online]. 2014, 1, p. 115-124. ISSN 2214-5095. Available from: https://doi.org/10.1016/j.cscm.2014.06.001

[29] GARDZIEJCZYK, W. Comparison of vehicle noise on dry and wet road surfaces. Foundations of Civil and Environmental Engineering. 2007, 9, p. 5-15. ISSN 1642-9303.

[30] FREITAS, E., PEREIRA, P., DE PICADO-SANTOS, L., SANTOS, A. Traffic noise changes due to water on porous and dense asphalt surfaces. Road Materials and Pavement Design [online]. 2009, 10(3), p. 587-607. ISSN 1468-0629, eISSN 2164-7402. Available from: https://doi.org/10.1080/14680629.2009.9690215 
[31] SARKAN,B., STOPKA, O.,LI, CH. Theissues of measuring the exterior andinteriornoise of roadvehicles. Communications - Scientific Letters of the University of Zilina [online]. 2017, 19(2), p. 50-55. ISSN 1335-4205, eISSN 2585-7878. Available from: http://komunikacie.uniza.sk/index.php/communications/article/view/182

[32] Republic of Poland. Journal of laws (in Polish). No. 140. Item 824. 2011.

[33] Republic of Poland. Journal of laws (in Polish). Item 112. 2014.

[34] Word Health Organization. Noise guidelines. Environmental noise guidelines for European Region. Executive summary. 2018. ISBN 9789289053563.

[35] Republic of Poland. Journal of laws (in Polish). No. 120. Item 826. 2007.

[36] Noise increases with vehicle speed [online] [accessed 2020-02-04]. Available from: https://www.nonoise.org/resource/ trans/highway/spnoise.htm

[37] Environmental noise - European Environment Agency [online] [accessed 2020-01-30]. Available from: https://www.eea. europa.eu/airs/2018/environment-and-health/environmental-noise

[38] PERZYNSKI, T., LEWINSKI, A. (2019) Selected telematics solutions in city transport. In: Development of Transport by Telematics TST 2019: proceedings [online]. Vol 1049. Communications in Computer and Information Science. MIKULSKI, J. (ed.). Cham, Springer, 2019. ISBN 978-3-030-27546-4, eISBN 978-3-030-27547-1, p. 202-215. Available from: https://doi.org/10.1007/978-3-030-27547-1_16

[39] TURCSANY, J. Electric buses and noise [online] [accessed 2020-01-28]. Available from: http://www.bullernatverket.se/ wp-content/uploads/2014/05/Electric-buses-and-noise_Volvo-Bus.pdf

[40] GREGOR, M., JANOTA, A., SLOVACEK, L. (2019). Optimization of fixed time control of road intersection by evolution strategies. In: Development of Transport by Telematics TST 2019: proceedings [online]. Vol 1049. Communications in Computer and Information Science. MIKULSKI, J. (ed.). Cham, Springer, 2019. ISBN 978-3-030-27546-4, eISBN 978-3-030-27547-1, p. 151-164. Available from: https://doi.org/10.1007/978-3-030-27547-1_12 